\title{
Effects of the zebra mussel on nitrogen dynamics and the microbial community at the sediment-water interface
}

\author{
Peter J. Lavrentyev ${ }^{1, *}$, Wayne S. Gardner ${ }^{2, * *}$, Longyuan Yang ${ }^{3}$ \\ ${ }^{1}$ University of Michigan, Cooperative Institute for Limnology and Ecosystem Research, 2200 Bonisteel Boulevard, \\ Ann Arbor, Michigan 48109, USA \\ ${ }^{2}$ National Oceanographic Atmospheric Administration, Great Lakes Environmental Research Laboratory, \\ 2205 Commonwealth Boulevard, Ann Arbor, Michigan 48105, USA \\ ${ }^{3}$ Chinese Academy of Sciences, Nanjing Institute of Geography and Limnology, 73 East Beijing Road, Nanjing, \\ Jiangsu 21008, PR China
}

\begin{abstract}
A flow-through experiment was conducted on intact cores of sediments from Saginaw Bay, Lake Huron, to examine how trophic interactions between filter-feeding bivalve mussels and microbial populations could affect nitrogen dynamics at the sediment-water interface. The zebra mussels used in this experiment removed a large proportion of protozoa and phytoplankton from the overlying water, particularly heterotrophic nanoplankton (up to $82 \%$ ), while bacterial populations showed less change. A 3 -fold decrease in the protozoan to bacterial carbon ratio corresponded to a 2.5 -fold increase in relative ammonium removal rates as estimated from the dark loss of ${ }^{15} \mathrm{~N}$-ammonium. Excretion by the bivalves also increased net ammonium flux to the water, thus elevating the total calculated areal ammonium removal rates to about 6 -fold over rates observed in the control treatment. These data suggest that filter-feeding bivalves may significantly affect nitrogen transformation rates near the sediment-water interface by excreting ammonium and altering the microbial food web structure at the sediment-water interface.
\end{abstract}

KEY WORDS: Nitrogen - Microbial food web - Sediment-water interface · Bivalve mussels

\section{INTRODUCTION}

The sediment-water interface is a region of active biological and biogeochemical processes, such as labile organic matter biodegradation and ammonium production in shallow coastal systems. Under such conditions, kinetic diffusion-reaction models based on equilibration of ammonium between the sediments and pore water do not adequately predict actual ammonium flux into overlying waters (Ullman \& Aller 1989).

\section{Present addresses:}

- University of Akron, Department of Biology, Akron, Ohio 44325-3908, USA. E-mail: peterl@uakron.edu

-University of Texas at Austin, Marine Science Institute, 750 Channel View Drive, Port Aransas, Texas 78373, USA
If oxygen is present, as often is the case in shallow waters, a portion of ammonium may be oxidized to nitrate (Ward 1986). In turn, the nitrate may be completely or partially denitrified to nitrogen gas in adjacent sites (Seitzinger 1988). Understanding the mechanisms that control the extent of $\mathrm{N}$ transformations at the sediment-water interface is important, because these processes can affect the amount of mineralized $\mathrm{N}$ that is ultimately available to primary producers or lost through denitrification.

Trophic cascades involving bacterivorous protozoa can affect community $\mathrm{N}$ regeneration rates (Suzuki et al. 1996) and bacterial community structure in the water column (Jürgens \& Güde 1994). Furthermore, planktonic bacterivorous protozoa can inhibit the biogeochemical process of nitrification, directly by reducing 
bacterial numbers and indirectly by forcing bacteria to grow in colonies, whereas predation by larger zooplankton diminishes these effects (Lavrentyev et al. 1997). The important role of the bottom-dwelling protozoa in consuming heterotrophic bacterial production (e.g. Bak et al. 1995) supports the idea that similar cascading trophic effects on nitrogen transformation may take place at the sediment-water interface. Here, microorganisms are involved in complex interactions with other benthic organisms that have significant effects on nitrogen transformations (Dame et al. 1984, 1991, Henriksen \& Kemp 1988).

One of these organisms is the zebra mussel Dreissena polymorpha, an invasive filter-feeding bivalve that alters the structure of food webs in shallow areas by filitering particies (e.g. Naiepa et ai. 1995) and excreting nutrients (Gardner et al. 1995b, Binelli et al. 1997). In this study, we examined how trophic interactions, induced by zebra mussels, can modify the microbial food web structure and nitrogen transformations at the sediment-water interface.

Studying trophic interactions and nutrient transformations involving microorganisms at the sedimentwater interface presents methodological difficulties. The use of a ${ }^{15} \mathrm{~N}$ tracer is necessary to study $\mathrm{N}$ dynamics because of close coupling between ammonium regeneration, nitrification, and denitrification. The mass analysis techniques for ${ }^{15} \mathrm{~N}$ require large sample volumes and involve multi-step sample preparations that increase the risk of contamination. The physical, chemical and biological nature of the sedimentary matrix is impossible to replicate in the laboratory; yet, the maintenance of this structure is crucial to many benthic processes (Miller-Way \& Twilley 1996). The necessity to maintain sediment integrity during an experimental incubation limits the application of conventional size-fractionation and dilution techniques that are commonly used to modify food web structure in planktonic studies. Further, the presence of meroplanktonic protozoa, which are able to migrate freely between sediments and the water column, may greatly diminish the effects of experimental manipulations with inlet water in such studies.

The purpose of this study was to examine how trophic interactions between filter-feeding bivalve mussels and microbial populations could change nitrogen dynamics in controlled experimental systems using intact sediments. To simulate a trophic cascade, we used the zebra mussel as a 'biological particle filter' in a sediment core continuous flow cell. We used this approach in combination with high performance liquid chromatographic analysis of ammonium concentration and atom $\%{ }^{15} \mathrm{~N}$ to test the hypothesis that cascading trophic effects involving bacterivorous protists affect nitrogen transformation at the sediment-water interface.

\section{MATERIAL AND METHODS}

Material for this study was collected from Saginaw Bay, a large (about $82 \mathrm{~km}$ long and $42 \mathrm{~km}$ wide) bay extending off the western edge of Lake Huron. The shallow (1 to $3.5 \mathrm{~m}$ depth) inner bay receives large inflows of enriched waters from the Saginaw River. Since 1991, the zebra mussel has heavily infested the inner bay (Nalepa et al. 1995).

Intact cores of sediments and the overlying water were collected by SCUBA divers from a site near $\mathrm{Au}$ Gres Point $\left(43^{\circ} 56^{\prime} \mathrm{N}, 83^{\circ} 52^{\prime} \mathrm{W}\right)$ on June 30, 1995. These samples were taken using $76 \mathrm{~mm}$ internal diameter plastic tubes. Simultaneously, several pebbles colonized by the zebra mussel were collected for experimental additions. Severai 20 i carboys of surface water from the same site were collected to supply a flowthrough system. The samples were transported to the laboratory in insulated coolers within a few hours after collection.

The sediments were placed in a system consisting of the cores (in the original collection tubes), a clear polycarbonate vessel with intake lake water, a Technicon peristaltic pump, and an outflow collection vessel (Fig. 1). This laminar flow system is an improved and larger version of the flow-cell described earlier (Gardner et al. 1991). It was designed with an O-ring seal and plunger that could be lowered to the desired position without disturbing the surface sediments. The overflow tube released water as the plunger was positioned but was closed during operation. Water was pumped over the sediment surface at a rate of $1 \mathrm{ml} \mathrm{min}^{-1}$.

The pebbles holding the zebra mussels were of different size and shape and had large amounts of periphyton on them. Mussels were removed from the pebbles by cutting the byssal threads with a razor blade

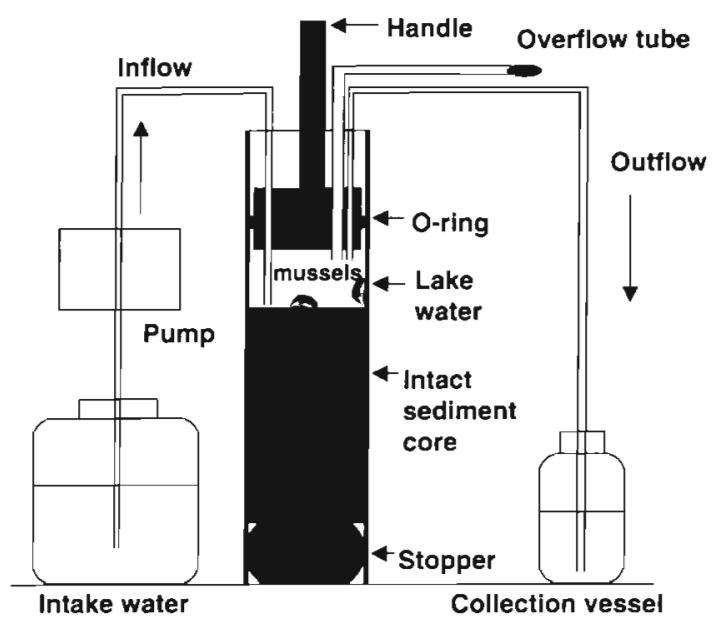

Fig. 1. The continuous flow through system. The diameter of the core was $76 \mathrm{~mm}$. The flow rate for the unfiltered water was $1 \mathrm{ml} \mathrm{min}{ }^{-1}$ 
and rinsed with bay water to remove periphyton before they were used in the experiment. Two adult mussels, shell length $22.3 \mathrm{~mm} \pm 0.69 \mathrm{SE}$, were added to each triplicate core. By the time the system had reached steady state, the zebra mussels remained either on the top of the sediments or attached to the side of the core tube above the sediment surface. Thus, they were positioned to filter overlying water rather than pore water. All zebra mussels remained alive during the experiment and were still filtering water at the end of the incubation.

The cores and the inflow water from the sample site were incubated in an indoor Percival incubator that was set for a 12:12 h light:dark cycle and held at ambient temperature $\left(21^{\circ} \mathrm{C}\right)$. The inlet water was held under fluorescent lights to ensure phytoplankton growth. Triplicate cores with mussels and triplicate controls without mussels were each assembled and wrapped in aluminum foil to prevent light penetration and make it possible to differentiate between removal by nitrification/denitrification and algal uptake. Large quantities of light (both visible and UV lengths) can inhibit nitrification via photooxidation of bacterial cytochrome $c$ (Bock et al. 1989).

The concentrations of $\mathrm{NH}_{4}{ }^{+}$and nitrates (equals $\mathrm{NO}_{2}{ }^{-}+\mathrm{NO}_{3}{ }^{-}$) were monitored over time. Ammonium concentrations and ${ }^{15} \mathrm{NH}_{4}{ }^{+}$isotope ratios were respectively measured via 2 high performance liquid chromatography methods (Gardner \& St. John 1991, Gardner et al. 1995a). Concentration of nitrates was measured using a standard colorimetric technique (Strickland \& Parsons 1972) with a Technicon autoanalyzer.

After the system had been maintained at steady state (based on the concentrations of dissolved nutrients) for $3 \mathrm{~d},{ }^{15} \mathrm{~N}$-ammonium isotope (10 $\mu \mathrm{M}$ final concentration) was added into the container with inflow water and mixed thoroughly. The additions of $10 \mu \mathrm{M}^{15} \mathrm{NH}_{4}{ }^{+}$were selected to provide concentrations of ammonium comparable to those produced in the sediments. Some ammonium (approximately $40 \%$ for the example in Table 1 ) was removed by organisms in the water before the water was passed over the cores. Of the water coming out of the cores, the labeled ammonium constituted 20 to $54 \%$ of the total ammonium. Note, the actual concentration of dissolved ${ }^{15} \mathrm{NH}_{4}{ }^{+}$in the water varied from day to day because of biological uptake after spiking. After allowing the system to equilibrate over night with the added ${ }^{15} \mathrm{NH}_{4}{ }^{+}$, we performed 3 sequential ${ }^{15} \mathrm{~N}$-incubation intervals and measured ammonium concentration and atom $\%{ }^{15} \mathrm{~N}$ within each interval to increase statistical robustness of the experiment.

Concentrations of ${ }^{15} \mathrm{NH}_{4}{ }^{+}$(i.e. $\mathrm{NH}_{4}{ }^{+}$concentration $x$ atom $\%{ }^{15} \mathrm{~N}$ ) were measured in the inflow waters and outflow waters, which were sampled at about the same time. We believe that phytoplankton uptake during passage across the dark core should not have exceeded that occurring in the inlet water held under light/dark conditions. Therefore, the observed differences in ${ }^{15} \mathrm{NH}_{4}{ }^{+}$concentrations between the inflow and outflow waters were assumed to result from microbial processes at or near the sediment-water interface.

Results from the flow-through core system, without (incubation Days 2, 3, and 4) and with (incubation Days 5, 6, and 7) ${ }^{15} \mathrm{NH}_{4}{ }^{+}$additions, were used to calculate ammonium removal rates. Successive results from each core were averaged before $(n=3)$ and after ( $\mathrm{n}=3$ ) addition of ${ }^{15} \mathrm{NH}_{4}{ }^{+}$to yield core-specific ammonium concentration and isotope ratio values. The corespecific values were than averaged among replicate core treatments to calculate mean values and standard errors (SE) for the zebra mussel and control treatments, respectively, before and after ${ }^{15} \mathrm{NH}_{4}{ }^{+}$additions. We assumed that the same percentage of ammonium was removed, whether it was released from the sediments, excreted by organisms, or added to the inlet water as ${ }^{15} \mathrm{NH}_{4}{ }^{+}$. Net areal ammonium flux $\left(N_{\text {net, }} \mu \mathrm{mol} \mathrm{N} \mathrm{m}{ }^{-2} \mathrm{~h}^{-1}\right)$ was calculated as follows:

$$
\begin{gathered}
N_{\text {net }}=\left(N_{O}-N_{\mathrm{I}}\right) \times \text { flow rate } / \text { core surface area } \\
=\left(N_{O}-N_{\mathrm{I}}\right) \times 13.3
\end{gathered}
$$

where $N_{O}$ and $N_{\mathrm{I}}$ were ammonium concentrations $(\mu \mathrm{M})$ in the outflow and inflow waters, respectively, during Days 2, 3 and 4, before the addition of ${ }^{15} \mathrm{NH}_{4}{ }^{+}$. The flow rate was $0.060 \mathrm{I} \mathrm{h}^{-1}$ and the surface area of the core was $0.0181 \mathrm{~m}^{2}$. Total ammonium flux $\left(N_{\text {total }}, \mu \mathrm{mol} \mathrm{N}\right.$ $\mathrm{m}^{-2} \mathrm{~h}^{-1}$ ), i.e. $N_{\text {net }}$ corrected for estimated removal, was then calculated as:

$$
N_{\text {total }}=N_{\text {net }} \times{ }^{15} N_{1} /{ }^{15} N_{O}
$$

where ${ }^{15} N_{\mathrm{I}}$ and ${ }^{15} \mathrm{~N}_{\mathrm{O}}$ are the concentrations of ${ }^{15} \mathrm{NH}_{4}{ }^{+}$ (i.e. total ammonium concentration $\times$ atom $\%{ }^{15} \mathrm{NH}_{4}{ }^{+}$) in the inflow and outflow waters, respectively. Note, this calculation is based on the assumption that the $\mathrm{NH}_{4}{ }^{+}$originating from the sediments or benthos was removed at the same relative rate as the added ${ }^{15} \mathrm{NH}_{4}{ }^{+}$. Finally, the amount of the removed ammonium ( $\left.N_{\text {removed }}\right)$ on an areal basis ( $\mu \mathrm{mol} \mathrm{N} \mathrm{m}{ }^{-2} \mathrm{~h}^{-1}$ ) was calculated as:

$$
N_{\text {removed }}=N_{\text {total }} \times\left({ }^{15} N_{\mathrm{I}}-{ }^{15} N_{\mathrm{O}}\right) /{ }^{15} N_{\mathrm{l}}
$$

The concentrations of bacteria, phytoplankton, and protozoa in the inflow and outflow water were measured at the beginning and the end of ${ }^{15} \mathrm{NH}_{4}{ }^{+}$incubations. Bacteria preserved with $1 \%$ (final concentration) formaldehyde were counted on acriflavine-stained filters (Bergstrom et al. 1986). Nanoplankton were preserved with ice-cold glutaraldehyde ( $1 \%$ final concentration) and counted using DAPI/FITC double staining (Sherr et al. 1993). Microplankton preserved with freshly prepared acid Lugol's iodine (1\% final concentration) were counted in settling chambers. Microbial 
cell linear dimensions were measured using an eyepiece micrometer (magnification up to $1250 \times$ ) and their biovolumes were calculated by approximating geometric solids. Allometric relationships (Norland 1993) were used to estimate bacterial biomass from their cell volume and then an average of these estimates was calculated. Protozoan biomass was estimated assuming carbon contents of 0.15 and $0.19 \mathrm{pg} \mathrm{C} \mathrm{m}^{-3}$ for living and preserved cells, respectively (Putt \& Stoecker 1989). Algal biovolumes were converted to carbon using the allometric equation for phytoplankton (Montagnes et al. 1994).

Under steady state, successive determinations of ${ }^{15} \mathrm{~N}$ dark losses and microbial parameters were averaged to obtain a single value for each flow-through chamber, and then a mean and standard error were calculated for triplicate experimental treatments and control.

At the end of the incubation, triplicate samples of sediments were collected from each core to estimate abundance of benthic protozoa. Benthic protozoa were counted in several $100 \mu \mathrm{l}$ subsamples of non-preserved sediments, which were diluted 1:10 with $0.2 \mu \mathrm{m}$ filtered lake water (Finlay et al. 1979). Heterotrophic nanoflagellates, preserved with $1 \%$ (final concentration) glutaraldehyde, were extracted from the sediments using isopycnic centrifugation in silica gel gradients (Epstein 1995) and counted via epifluorescence microscopy as described above.

\section{RESULTS}

After some initial oscillation of nutrient concentrations in control and experimental cores with added zebra mussels over the first $24 \mathrm{~h}$, the flow-through system stabilized (Fig. 2). The concentration of $\mathrm{NH}_{4}{ }^{+}$in both triplicate outflows remained significantly higher than in the inflows throughout the experiment, indicating a positive flux of $\mathrm{NH}_{4}{ }^{+}$from the sediments and benthic organism excretion. Mean net ammonium production rate $\left(117 \pm 18\right.$ [SE], $\left.\mu \mathrm{mol} \mathrm{N} \mathrm{m} \mathrm{N}^{-2} \mathrm{~h}^{-1}\right)$ was significantly higher in the zebra mussel treatments than in the control treatments $\left(59 \pm 16[\mathrm{SE}], \mu \mathrm{mol} \mathrm{N} \mathrm{m}^{-2} \mathrm{~h}^{-1}\right)$. Conversely, the concentration of nitrates was slightly higher in the inflows than in both outflows, which did not differ from each other. Sequential measurements of ammonium production rates in individual cores consistently varied less than the mean results obtained from replicate cores (data not shown). Likewise, variability among cores was greater for the concentrations and fluxes of total ammonium produced by natural mineralization processes than for the ${ }^{15} \mathrm{~N}$-labeled ammonium that had been added on both an absolute and relative basis (Table 1).

The mean percentage of ${ }^{15} \mathrm{NH}_{4}{ }^{+}$removed as the spiked water moved over the sediment cores was $10 \pm 2.0$ (SE) \% for the control treatments as compared to $26 \pm 9 \%$ for the zebra mussel treatments. The mean total ammonium flux and removal rate, calculated by Eqs. (2) \& (3), respectively, were $68 \pm 18$ and $7.3 \pm 2.5 \mu \mathrm{mol} \mathrm{N} \mathrm{m}^{-2} \mathrm{~h}^{-1}$ for the control treatment sediments as compared to $169 \pm 30$ and $46 \pm 12 \mu \mathrm{mol} \mathrm{N}$ $\mathrm{m}^{-2} \mathrm{~h}^{-1}$ for the zebra mussel treatments.

The biomass of phytoplankton was largely formed by nanoplankton-sized diatoms, cryptophytes, and Chlamydomonas sp. It slightly increased in the control due to the large Cymbella sp. and Pediastrum sp. that may

Table 1. Total $\mathrm{NH}_{4}{ }^{+}$and ${ }^{15} \mathrm{NH}_{4}{ }^{+}$(= total concentration times atom $\%{ }^{15} \mathrm{~N}$ ) concentrations $( \pm \mathrm{SE})$ in inflow water and outflow waters for each time point (T6, T7, and T8) in the ${ }^{15} \mathrm{NH}_{4}{ }^{+}$-addition experiments. All concentrations are expressed as $\mu \mathrm{M} \mathrm{N}$

\begin{tabular}{|lrrrrrrr} 
& \multicolumn{2}{c}{$\mathrm{T} 6$} & \multicolumn{2}{c}{$\mathrm{T}$} & \multicolumn{2}{c}{$\mathrm{T} 8$} \\
& Total & ${ }^{15} \mathrm{NH}_{4}{ }^{+}$ & Total & ${ }^{15} \mathrm{NH}_{4}{ }^{+}$ & Total & ${ }^{15} \mathrm{NH}_{4}{ }^{+}$ \\
\hline Inflow & 5.9 & 4.4 & 6.7 & 5.7 & 5.9 & 4.7 \\
Control & & & & & & \\
Mean & 10.3 & 4.2 & 11.0 & 5.9 & 9.6 & 3.3 \\
SE & 1.2 & 0.1 & 1.1 & 0.2 & 1.2 & 0.2 \\
Zebra mussel & & & & & & \\
Mean & 15.8 & 3.7 & 15.4 & 4.7 & 13.2 & 2.6 \\
SE & 1.6 & 0.2 & 1.7 & 0.4 & 1.6 & 0.2 \\
\hline
\end{tabular}



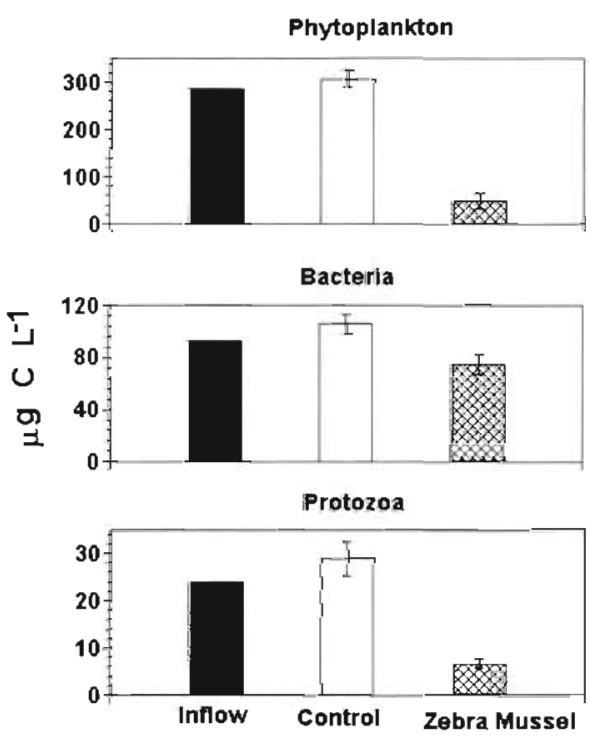

Fig. 3. Mean biomass $( \pm \mathrm{SE})$ of microorganisms during ${ }^{15} \mathrm{~N}$ incubations

have been flushed from the sediments. All groups of phytoplankton, with the exception of the colonial cyanobacterium Merismopedia sp., drastically decreased in the zebra mussel treatments (Fig. 3).

In the control, there was no appreciable change in biomass and species composition of the ciliate assemblage, which consisted mainly of oligotrichs and Urotricha spp. The occurrence of the benthic scuticociliate Uronema sp. in the outflow water did not significantly affect the total ciliate biomass. However, in the treatments with zebra mussels, there was a ca 2 -fold decline in protozoan biomass. The most dramatic change was observed for heterotrophic nanoflagellates (HNAN). Their biomass decreased by $82 \%$ in the zebra mussel treatments.

Bacterial biomass showed a similar trend to that of protozoa but in much smaller proportion. The observed changes were mainly accounted for by large $(>1 \mu \mathrm{m})$ and chain-forming rod- and vibrio-shaped cells that represented ca $25 \%$ of the total bacterial biomass in the inflow, $>40 \%$ in the control outflow, and $<8 \%$ in the zebra mussel outflow.

The ratio of protozoan to bacterial carbon-based biomass decreased from $27.3 \pm 2.45$ (SE) in the control to $8.72 \pm 1.39$ in the zebra mussel treatments. The ratio of HNAN to bacterial biomass declined even stronger, $0.16 \pm 0.03$ in the control versus $0.03 \pm 0.01$ in the zebra mussel treatments. As mentioned above, the percentage of ${ }^{15} \mathrm{~N}$ lost during the passage of water through the core treatments was also significantly higher in the grazed treatments than in the control.

The total biomass of benthic protozoa ( $\mu \mathrm{g} \mathrm{C} \mathrm{ml}^{-1}$ ), sampled in the sediments at the end of the experiment, did not significantly differ between the treatments, $0.53 \pm 0.07(\mathrm{SE})$ in the control versus $0.70 \pm 0.08$ in the zebra mussel cores. However, the proportional contribution of the small scuticociliate Uronema sp. was nearly twice as high in the latter treatment, where it comprised ca $60 \%$ of the protozoan biomass in the sediments. In the control, the more diverse protozoan assemblage was reflected in the quantitative presence of large ciliates, such as Spirostomum minus, Loxodes sp., and Oxytricha sp., and a substantial contribution from HNAN. The ciliate Saprodinium sp. occurred in both treatments.

\section{DISCUSSION}

A steady-state response in our experiments, where ammonium and nitrate fluxes remained stable over time, supported the observation of Miller-Way \& Twilley (1996) that continuous flow systems can maintain near-initial experimental conditions throughout incubation. Net production and changes in atom $\%{ }^{15} \mathrm{~N}$ were measurable in all of the cores. Variability of the ${ }^{15} \mathrm{NH}_{4}{ }^{+}$concentrations and fluxes among cores at a given time point were consistently lower than those for the total ammonium concentrations. These results indicate that the ratio of ammonium removal to production rates in the nepheloid layer was not greatly affected by the magnitude of total ammonium concentration or production rate, at least within the ranges of data that were examined here. Net sediment-water ammonium fluxes reported here are similar to those previously measured in Saginaw Bay (Ullmman \& Aller 1989).

Both ammonium flux and nitrification rate increased significantly in the presence of the zebra mussels. Interestingly, even though total $\mathrm{NH}_{4}{ }^{+}$fluxes were higher, the percentage of the total ammonium flux that was taken up increased by 2.5 -fold in the zebra mussel treatments as compared to results from the control treatments. Thus, the presence of zebra mussel not only affected absolute ammonium removal rates but also increased the percentage of regenerated ammonium that was removed. Increased ammonium removal rates partially counterbalanced increased ammonium production rates in the presence of the zebra mussel. Positive shifts in the $\mathrm{NH}_{4}$ : $\mathrm{NO}_{3}$ ratio have been reported to trigger blooms of non-nitrogen-fixing cyanobacteria, such as Microcystis (Blomqvist et al. 1994).

Given the drastic decrease in phytoplankton biomass that was observed in the zebra mussel outflow, the increased dark loss of ${ }^{15} \mathrm{NH}_{4}{ }^{+}$in this treatment was likely more the result of enhanced nitrification than of algal uptake. The lack of corresponding changes in nitrate concentrations can be explained by coupled nitrate losses to denitrification that may have occurred close to the sediment-water interface (Gardner et al. 1987, Henriksen \& Kemp 1988). The zebra mussel can 
stimulate the development of benthic microalgae in Saginaw Bay (Lowe \& Pilsbury 1995), but we expect that $N$ uptake by these organisms may have been small during the prolonged dark incubation. The occurrence of the benthic ciliate Saprodinium sp. indirectly suggests that anoxic conditions conductive to denitrification may have existed in certain regions of sediments in this experiment.

The mechanisms underlying the zebra mussel effects on microbial nitrogen transformations in this study appear to be different from those reported for other macrobenthos. In our experiments, the zebra mussels remained either on the top of the sediments or attached to the side of the core tube above the sediment surface. Thus, they were positioned to filter overlying water rather than pore water. The fact that the sediments were firm sand rather than clay prevented the mussels from penetrating extensively into the sediment matrix. Unlike many other sedimentdwelling macrofauna, which aerate sediments via their bioturbation activities (Pelegri \& Blackburn 1995, Rysgaard et al. 1995, Svensson \& Leonardson 1996), the zebra mussel does not burrow into the sediments, but forms dense beds on solid substrates at the sediment surface.

In Saginaw Bay, the zebra mussel deposits large amounts of feces and pseudofeces at the sediment surface (Nalepa et al. 1995) and significantly enhances $\mathrm{N}$-cycling rates by excreting ammonium (Gardner et al. 1995b). However, the concentrations of $\mathrm{NH}_{4}{ }^{+}$were not limiting to microorganisms even in the absence of zebra mussel, as indicated by the positive net $\mathrm{NH}_{4}{ }^{+}$ flux from the control cores. Under nitrogen-limited conditions, which are more typical for marine systems, nitrification may be enhanced by $\mathrm{NH}_{4}{ }^{+}$-rich fecal pellets placed on the sediment surface (Henriksen \& Kemp 1988).

Our results are consistent with the idea that cascading trophic phenomena could directly affect the transformation and fate of mineralized nitrogen at the sediment-water interface. The zebra mussel filtering process appeared to selectively remove algae and bacterial grazers from the overlying water. This observation corresponds well to the results of earlier studies, where the mussel drastically reduced the abundance of phyto- and protozooplankton (Leach 1993, Lavrentyev et al. 1995, Bastviken et al. 1998, Findlay et al. 1998). The size-based prey selectivity of filter-feeding mussels appears to determine their cascading effects on bacteria. Having a typical filtration rate of ca $50 \mathrm{ml}$ mussel ${ }^{-1} \mathrm{~h}^{-1}$ (Reeders \& de Vaate 1990), the zebra mussel is capable of filtering particles from 0.7 to $450 \mu \mathrm{m}$ (Jørgensen et al, 1984), but maximum retention occurs in the size range from 5 to $35 \mu \mathrm{m}$ (Sprung \& Rose 1988). Heterotrophic nanoflagellates, the major bacterivorous organisms in Saginaw Bay (Lavrentyev et al. 1997), fall within this size category.

Bacterial biomass did not differ significantly between the control and the treatments with zebra mussels, despite a strong decline in protozoan abundance in the latter treatments. Combined with the observed changes in bacterial size structure, this fact implies that mussels may have removed a certain proportion of the bacterial population from the overlying water. However, in the latter treatment, a decrease in the protozoan to bacterial biomass ratio, possibly reflecting the degree of bacterivory, corresponded to an increase in the dark ${ }^{15} \mathrm{~N}$ loss. This result suggests that a sharp reduction in HNAN numbers allowed bacterial activity to increase. In Saginaw Bay, the zebra mussel grazed a certain proportion of the bactenai population, but their overall effect on bacterial production in the water column in Saginaw Bay was stimulating (Cotner et al. 1995). Protozoa can selectively graze metabolically active bacteria (del Georgio et al. 1996, López-Amorós et al. 1998). Although some bivalve mussels are capable of assimilating bacterial food due to their flexible digestive system (Dech \& Luoma 1996), it is unlikely that a similar level of selectivity can occur in them.

The potential cascading trophic effect of Dreissena polymorpha on the microbial community appears to be similar to those described for planktonic heterotrophic (Jürgens \& Güde 1994) and nitrifying bacteria (Lavrentyev et al. 1997). Although we did not measure bacterivory rates in these experiments, our earlier experiments in Saginaw Bay (Lavrentyev et al. 1997) identified HNAN as major consumers of bacteria. Moreover, we found that HNAN were capable of efficiently removing nitrifying bacteria, even when these bacteria were present at very low concentrations.

The effects of bivalve activities appear to be more complex in the sediments than in the overlying water. It is reasonable that the organic-rich feces and pseudofeces deposited by the zebra mussel at the sediment surface could have stimulated the growth of heterotrophic bacteria in sediments that, in turn, may have caused the observed shift toward a predominance of scuticociliates in microbenthic community. These specialized bacterivorous ciliates have much higher specific grazing rates upon bacteria than do HNAN (e.g. Simek et al. 1994). However, the lack of direct measurements of bacterial biomass in sediments inhibits further speculation at this point.

Trophic links between microorganisms and bottomdwelling invertebrates are not unique to the zebra mussel and the freshwater environment. The estuarine bivalve Mytilus edulis affected microzooplanktonsized ciliates (Riemann et al. 1990) and preyed upon bacterivorous heterotrophic flagellates (Kreeger \& Newell 1996). The oyster Crassostrea gigas has been 
recently found to assimilate ciliates and flagellates (Dupuy et al. 1999).

Combined with these observations, the results of our study suggest a new interpretation of previously published data on the effects of marine invertebrates on the nitrification process. For example, in the Chukchi Sea, the large bivalve Macoma calcera stimulated nitrification despite the fact that it excreted directly to the water column through its exhalant siphon with little irrigation effect in the sediments (Henriksen et al. 1993). One explanation that agrees with these results is that the bivalves could have stimulated nitrification by filtering out bacterivorous protozoa that would otherwise graze nitrifying bacteria.

Another marine study found that sponges positively affected nitrification rates (Diaz \& Ward 1997). The difference in accumulation of nitrite and nitrate in the presence of different species of sponges in that study led to the conclusion that bacteria directly associated with the sponges caused that nitrification. However, these data are also interesting with respect to our hypothesis regarding cascading trophic effects on the nitrification process. Filter-feeding sponges could reasonably reduce the numbers of bacterivorous protozoa, which could otherwise graze down both suspended and surface-associated nitrifier cells.

Although we did not attempt to represent all actual complex processes at the sediment-water interface in our laboratory study, we believe that these data offer some preliminary insight into the effects that bivalves such as the zebra mussel may have on nitrogen dynamics in nature. The cascading trophic effects could be quantitatively important to the transformations and fluxes of nitrogen in certain sediment-water environments (e.g. shallow productive areas of lakes, estuaries, and the coastal ocean). Conducive features include both an environment favorable for active microbial processes (e.g. nitrification) and the presence of dense populations of bivalve mussels or other suspension-feeding invertebrates that can exert 'topdown' effects on microbial food web components. The above example of zebra mussel affecting microbial food web composition, as well as the fate of nitrogen at the sediment-water interface, points to the need for more research on the effects of cascading trophic effects on biogeochemical cycles at both regional and global scales.

Acknowledgements. This study was supported by the GLERL Non-Indigenous Species Program and in part by the Sea Grant No. NA16RG0457 to Jim Cotner. We thank Jim Cotner, Dave Fanslow, and Tom Johengen for collecting the mussels and sediment cores, Tom Johengen for help with nitrate analyses, and Joann Cavaletto for assistance in the laboratory.
The manuscript benefited from criticisms provided by 2 anonymous reviewers. This is GLERL contribution 1150 and UTMSI contribution 1128

\section{LITERATURE CITED}

Bak RPM, van Duyl FC, Neiuwland G (1995) Organic sedimentation and macrofauna as forcing factors in marine benthic nanoflagellate communities. Microb Ecol 29:173-182

Bastviken DTE, Caraco NF, Cole JJ (1998) Experimental measurements of zebra mussel (Dreissena polymorpha) impacts on phytoplankton community composition. Freshw Biol 39:375-386

Bergstrom I, Heinanen A, Salonen K (1986) Comparison of acridine orange, acriflavine, bisbenzimide stains for enumeration of bacteria in clear and humic waters. Appl Environ Microbiol 51:664-667

Binelli A, Provini A, Galassi S (1997) Modifications in Lake Como (N. Italy) caused by the zebra mussel (Dreissena polymorpha). Water Air Soil Pollut 99:633-640

Blomqvist P, Peterson A, Hyenstrand P (1994) Ammoniumnitrogen: a key regulatory factor causing dominance of non-nitrogen-fixing cyanobacteria in aquatic systems. Arch Hydrobiol 132:141-164

Bock E, Koops HP, Harms H (1989) Nitrifying bacteria. In: Brock TD, Schlegel HG (eds) Autotrophic bacteria. Science Tech, Madison, p 81-96

Cotner JB, Gardner WS, Johnson JR, Sada RH, Cavaletto JF, Heath RT (1995) Effects of zebra mussels (Dreissena polymorpha) on bacterioplankton: evidence of both size-selective consumption and growth stimulation. J Great Lakes Res 21:517-528

Dame RF, Zingmark RG, Haskin E (1984) Oyster reefs as processors of estuarine materials. J Exp Mar Biol Ecol 83: $239-247$

Dame RF, Dankers R, Prins T, Joncsma H, Smaal A (1991) The influence of mussel beds on nutrients in the Western Wadden Sea and Eastern Scheldt estuaries. Estuaries 14: $130-138$

Dech AW, Luoma N (1996) Flexible digestion strategies and trace metal assimilation in marine bivalves. Limnol Oceanogr 41:568-572

del Giorgio PA, Gasol JM, Vaqué D, Mura P, Agusti S, Duarte CM (1996) Bacterioplankton community structure: protists control net production and the proportion of active bacteria in a coastal marine community. Limnol Oceanogr 41 : $1169-1179$

Diaz MC, Ward BB (1997) Sponge-mediated nitrification in tropical benthic communities. Mar Ecol Prog Ser 156: 97-107

Dupuy C, Le Gall S, Hartmann HJ, Breret M (1999) Retention of ciliates and flagellates by the oyster Crassostrea gigas in French Atlantic coastal ponds: protists as a trophic link between bacterioplankton and benthic suspension-feeders. Mar Ecol Progr Ser 177:165-175

Epstein SS (1995) Simultaneous enumeration of protozoa and micrometazoa from marine sandy sediments. Aquat Microb Ecol 9:219-227

Findlay S, Pace ML, Fisher DT (1998) Response of heterotrophic bacteria to the zebra mussel invasion of the tidal freshwater Hudson River. Microb Ecol 36:131-140

Finlay BJ, Laybourn J, Shashan J (1979) A technique for enumeration of benthic ciliated protozoa. Oecologia 39:375-377

Gardner WS, St. John PA (1991) High-performance liquid chromatographic method to determine ammonium ion and primary amines in seawater. Anal Chem 63:537-540 
Gardner WS, Nalepa TF, Malczyk JM (1987) Nitrogen mineralization and denitrification in Lake Michigan sediments. Limnol Oceanogr 32:1226-1238

Gardner WS, Seitzinger SP, Malczyk JM (1991) The effects of sea salts on the forms of nitrogen released from estuarine and freshwater sediments: does ion pairing affect ammonium flux? Estuaries 14:157-166

Gardner WS, Bootsma HA, Evans C, St. John PA (1995a) Improved chromatographic analysis of ${ }^{15} \mathrm{~N}:{ }^{14} \mathrm{~N}$ ratios in ammonium or nitrate for isotopic addition experiments. Mar Chem 48:271-282

Gardner WS, Cavaletto JF, Johengen TH, Johnson JR, Heath RT, Cotner JB (1995b) Effects of the zebra mussels, Dreissena polymorpha, on community nitrogen dynamics in Saginaw Bay, Lake Huron. J Great Lakes Res 21:529-544

Henriksen K, Kemp WM (1988) Nitrification in estuarine and coastal marine sediments. In: Blackburn TH, Sørensen J (eds) Nitrogen cycling in coastal marine environments. Wiley \& Sons, Chichesier, p $20 \hat{0} \vec{f}-24 \hat{0}$

Henriksen K, Blackburn TH, Lomstein BAa, McRoy CP (1993) Rates of nitrification, distribution of nitrifying bacteria, and inorganic $\mathrm{N}$ fluxes in northern Bering-Chukchi shelf sediments. Cont Shelf Res 13:629-651

Jørgensen CB, Kiørboe T, Riisgård HU (1984) Ciliary and mucus-net filter feeding, with special reference to fluid mechanical characteristics. Mar Ecol Prog Ser 15:283-292

Jürgens K, Güde H (1994) The potential importance of grazing-resistant bacteria in planktonic systems: a review. Mar Ecol Prog Ser 112:169-188

Kreeger DA, Newell RIE (1996) Ingestion and assimilation of carbon from celluolytic bacteria and heterotrophic flagellates by the mussels Geukensia demissa and Mytilus edulis (Bivalva, Mollusca). Aquat Microb Ecol 11:205-214

Lavrentyev PJ, Gardner WS, Cávaletto JF, Beaver JR (1995) Effects of the zebra mussel (Dreissena polymorpha Pallas) on protozoa and phytoplankton in Saginaw Bay, Lake Huron. J Great Lakes Res 21:545-557

Lavrentyev PJ, Gardner WS, Johnson JR (1997) Cascading trophic effects on aquatic nitrification: experimental evidence and potential implications. Aquat Microb Ecol 13 $161-175$

Leach JH (1993) Impacts of the zebra mussel (Dreissena polymorpha) on water quality and fish spawning reefs in western Lake Erie. In: Nalepa TF, Schloesser DW (eds) Zebra mussels biology, impacts, and control. Lewis, Ann Arbor, p 381-388

López-Amorós R, Comas J, García MT, Vives-Rego J (1998) Use of the 5-cyano-2,3-ditolyl tetrazolium chloride reduction test to assess respiring marine bacteria and grazing effects by flow cytometry during linear alkylbenzene sulfonate degradation. FEMS Microbiol Ecol 27:33-42

Lowe RL, Pillsbury RW (1995) Shifts in benthic algal community structure and function following the appearance of zebra mussels (Dreissena polymorpha) in Saginaw Bay, Lake Huron. J Great Lakes Res 21:558-566

Miller-Way T, Twilley RR (1996) Theory and operation of continuous flow systems for the study of benthic-pelagic coupling. Mar Ecol Prog Ser 140:257-269

Montagnes DJ, Bergers JA, Harrison PJ, Taylor FJR (1994)

Editorial responsibility: Patricia Glibert,

Cambridge, Maryland, USA
Estimating carbon, protein, and chlorophyll a from volume in marine phytoplankton. Limnol Oceanogr 39:1044-1060

Nalepa TF, Wojcik JA, Fanslow DL, Lang GA (1995) Initial colonization of the zebra mussel (Dreissena polymorpha) in Saginaw Bay, Lake Huron: population recruitment, density, and size structure. J Great Lakes Res 21:417-434

Norland S (1993) The relationship between biomass and volume of bacteria. In: Kemp PF, Sherr BF, Sherr EB, Cole JJ (eds) Handbook of methods in aquatic microbial ecology. Lewis, Boca Raton, p 303-307

Pelegri SP, Blackburn TH (1995) Effect of bioturbation by Nereis sp., Mya arenaria and Cerastoderma sp. on nitrification and denitrification in estuarine sediments. Ophelia 24:289-299

Putt M, Stoecker DK (1989) An experimentally determined carbon:volume ratio for marine oligotrichous ciliates from estuarine and coastal waters. Limnol Oceanogr 34: $1177-1183$

Reeders HH, de Vaate AB (1900) Zebra mussels (Dreissena polymorpha): a new perspective for water quality management. Hydrobiologia 200/201:437-450

Riemann B, Sørensen HM, Bjørnsen PK, Horsted SJ, Jensen LM, Nielsen TG, Søndergaard M (1990) Carbon budgets of the microbial food web in estuarine enclosures. Mar Ecol Prog Ser 65:159-170

Rysgaard S, Christensen PB, Nielsen LP (1995) Seasonal variation in nitrification and denitrification in estuarine sediment colonized by benthic microalgae and bioturbating infauna. Mar Ecol Prog Ser 126:111-121

Seitzinger SP (1988) Denitrification in freshwater and coastal marine ecosystems: ecological and geochemical significance. Limnol Oceanogr 33:702-724

Sherr EB, Caron DA, Sherr BF (1993) Staining of heterotrophic protists for visualization via epifluorescence microscopy. In: Kemp PF, Sherr BF, Sherr EB, Cole JJ (eds) Handbook of methods in aquatic microbial ecology. Lewis, Boca Raton, p 213-228

Simek K, Vrba J, Lavrentyev PJ (1994) Estimates of protozoan bacterivory: from microscopy to ectoenzyme assay? Mar Microb Food Webs 8:71-85

Sprung M, Rose U (1988) Influence of food size and food quality on the feeding of the mussel Dreissena polymorpha. Oecologia 77:526-532

Strickland JDH, Parsons TR (1972) A practical handbook for seawater analysis, 2nd edn. Bull Fish Res Board Can 167

Suzuki M, Sherr EB, Sherr BF (1996) Estimation of ammonium regeneration efficiencies associated with bacterivory in pelagic food webs via a ${ }^{15} \mathrm{~N}$ tracer method. J Plankton Res 18:411-428

Svensson JM, Leonardson L (1996) Effects of bioturbation by tube-dwelling chironomid larvae on oxygen uptake and denitrification in eutrophic lake sediments. Freshw Biol 35:289-300

Ullman WJ, Aller RC (1989) Nutrient release rates from the sediments of Saginaw Bay, Lake Huron. Hydrobiologia $171: 127-140$

Ward BB (1986) Nitrification in marine environment. In: Prosser JI (ed) Nitrification. Oxford Univ. Press, Oxford, p $157-184$

Submitted: May 11, 1999; Accepted: October 25, 1999

Proofs received from author(s): February 29, 2000 